Controls, Metaphors and Contexts. An Approach to Cognition and Emotion // Bearson D.J., et al. (Eds.) / Developmental Perspectives. - 1986. - 162 р. 9. Вища освіта і болонський процес в Україні [Електронний ресурс] - Режим доступу: http://eduknigi.com/ped_ view.php?id=1

\title{
ВІРТУАЛЬНІ ДИНАМІЧНІ МОДЕЛІ ЯК ЗАСІБ ФОРМУВАННЯ ФАХОВИХ КОМПЕТЕНЦІЙ МАЙБУТНІХ ІНЖЕНЕРІВ-ПЕДАГОГІВ
}

Ігнатенко С. В. Віртуальні динамічні моделі як засіб формування фахових компетенцій майбутніх інженерів-педагогів.

У статті сформульовано визначення поняття «віртуальна динамічна модель», а також розглянуто дидактичні можливості ВДМ i доведено ефективність їх використання у процесі фахової підготовки майбутніх інженерів-педагогів.

Ключові слова: віртуальна динамічна модель, інженер-педагог, фахові компетенції.

Игнатенко С. В. Виртуальные динамические модели как средство формирования профессиональных компетенций будущих инженеров-педагогов.

В статье сформулировано определение понятия «виртуальная динамическая модель», а также рассмотрены дидактические возможности ВДМ и доказана эффективность их использования в процессе профессиональной подготовки будущих инженеров-педагогов.

Ключевые слова: виртуальная динамическая модель, инженер-педагог, профессиональные компетенции.

Ignatenko S. V. Virtual dynamic models as a means of forming professional competences of future engineer-educators.

The article defines the term "virtual dynamic model" and discusses the didactic possibilities for a virtual dynamic model. The author proves the effectiveness of their use in training future engineer-educators.

Key words: virtual dynamic model, engineer-educator, professional competences.

У XXI сторіччі суспільство характеризується як інформаційне, що формується на підставі досягнень науково-технічного прогресу.

Останніми роками велика увага приділяється застосуванню комп'ютерних моделей та віртуальних тренажерів. Використання комп'ютерного моделювання як інструменту навчальної діяльності дає можливість переосмислити традиційні підходи до вивчення дисциплін, посилити експериментальну та дослідницьку діяльність студентів, наблизити процес навчання до реального процесу пізнання.

Проблеми моделювання та використання інформаційних технологій у навчальному процесі $є$ підгрунтям наукових доробок багатьох наковців. М. Жалдак досліджує проблеми формування інформаційної культури майбутнього вчителя, змісту навчання інформатики в школі, створення й використання комп'ютерноорієнтованих дидактичних засобів навчання [1]. I. Образцов досліджує використання віртуальних тренажерів у практиці технічної освіти [3]. І. Теплицький опікується питаннями педагогічної технології комп'ютерного математичного моделювання [5]. Безпосередньо проблемою моделювання процесів, явищ також займаються 
I. Левіна [2], В. Пінькас [4] та ін.

Проте для ефективного впровадження віртуальних динамічних моделей у практичну діяльність викладача гостро постає питання розроблення методик використання віртуальних динамічних анімацій, а також їхнє узгодження 3 традиційними технологіями й методами навчання.

Здійснивши детальний теоретичний аналіз науково-педагогічної літератури та електронних ресурсів мережі Інтернет, ми не зустріли жодного визначення поняття «віртуальна динамічна модель».

Meта cmammi. Теоретичне обгрунтування, розроблення та експериментальна перевірка методики використання віртуальних динамічних моделей у процесі фахової підготовки майбутніх інженерів-педагогів в умовах ВН3.

Завданнями статті визначено:

- сформулювати визначення поняття «віртуальна динамічна модель»;

- визначити дидактичні можливості віртуальних динамічних моделей у процесі вивчення спеціальних технічних дисциплін;

- довести ефективність використання ВДМ у процесі фахової підготовки майбутніх інженерів-педагогів.

Розглядаючи поняття «віртуальна динамічна модель» (ВДМ), ми відмітили його складну природу. За допомогою аналітико-синтетичного методу, у процесі якого складне поняття було розкладене на кілька простих, наведено визначення всім простим поняттям окремо.

У даному випадку поняття «віртуальна динамічна модель» включає три складники: «модель», «динамічна (ий)» та «віртуальна (ий)». Визначаючи вагомість у терміні кожного складникаї, ми прийняли категорію «модель» за основу, вважаючи, що решта дві лише конкретизують іiі, вказують на функціональні ознаки. Результати понятійного аналізу наведено в табл. 1.

Таблиия 1

Основні характеристики складників поняття «віртуальна динамічна модель» (за різними авторами)

\begin{tabular}{|c|c|c|}
\hline \multicolumn{3}{|c|}{ Поняття } \\
\hline Динамічний (-a, -i) & Модель & Вірту \\
\hline 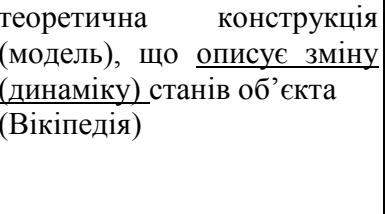 & $\begin{array}{l}\text { відтворює чи відображує } \\
\text { об'єкт; матеріал чи об'єкт } \\
\text { або явище, що є спрощеною } \\
\text { версією модельованого } \\
\text { об'єкта або явища } \\
\text { (Вікіпедія) }\end{array}$ & $\begin{array}{l}\text { Можливий, той, що не має } \\
\text { фізичного втілення, або той, } \\
\text { що в відрізняється } \\
\text { реальності } \\
\text { iншомовних } \\
\text { соціокультурних термінів) }\end{array}$ \\
\hline $\begin{array}{l}\text { системи, } \\
\text { відбуваються зміни } \\
\text { 3 часом. } \\
\text { (Ф. Перегудов, } \\
\text { Ф. Тарасенко) }\end{array}$ & $\begin{array}{l}\text { штучна система елементів, } \\
\text { яка відображає деякі } \\
\text { властивості, } \\
\text { 3в'язки об'єкта, що } \\
\text { досліджуються } \\
\text { (С. Гончаренко) } \\
\end{array}$ & $\begin{array}{l}\text { модель, яка відображає } \\
\text { ідеальне уявлення людей } \\
\text { про навколишній світ } \\
\text { (Вікіпедія) }\end{array}$ \\
\hline $\begin{array}{l}\text { вид моделей, яка дозволяє } \\
\text { побачити зміни об'єкта в } \\
\text { часі } \\
\text { (Н. Попова) }\end{array}$ & 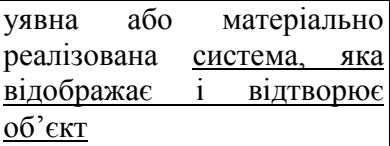 & 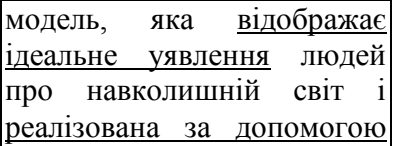 \\
\hline & & комплексних мультимедіа- \\
\hline
\end{tabular}




\begin{tabular}{|c|c|c|}
\hline \multicolumn{3}{|c|}{ Поняття } \\
\hline Динамічний (-a, -i) & Модель & Віртуальний (-a, -i) \\
\hline & & $\begin{array}{l}\text { операційних середовищ } \\
\text { (прийняте в дослідженні) }\end{array}$ \\
\hline \multirow[t]{3}{*}{$\begin{array}{l}\text { модель, серед параметрів } \\
\text { якої є часовий параметр } \\
\text { (І. Теплицький) }\end{array}$} & $\begin{array}{lrr}\text { система, } & \text { що } \\
\text { відрізняється } & \text { не } \\
\text { модельованого } & \text { об’єкта } \\
\text { відносно } & \text { деяких } \\
\text { властивостей, } & \text { що } \\
\text { вважаються істотними, і що } \\
\text { відрізняється } \\
\text { всіма } & \text { іншими } \\
\text { властивостям } & \\
\text { (А. Бочкін) } & \end{array}$ & \\
\hline & $\begin{array}{l}\text { спрощене уявлення про } \\
\text { реальний об'єкт, процес або } \\
\text { явище } \\
\text { (Н. Макарова) }\end{array}$ & \\
\hline & 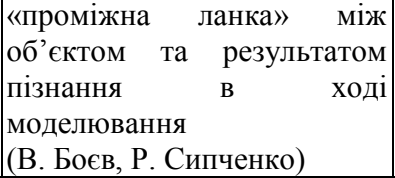 & \\
\hline
\end{tabular}

Систематизувавши отримані елементарні визначення, ми сформулювали визначення складного поняття.

Отже, віртуальна динамічна модель (ВДМ) - це реалізована за допомогою комплексних мультимедіа-операційних середовищ, штучна система елементів, що відтворює чи відображує об'єкт, описує зміну (динаміку) його станів, властивостей, сторін, зв'язків.

У процесі підготовки до практичних і лабораторних занять за традиційною технологією перед викладачами може виникнути низка проблем, що ускладнюють їх проведення та знижують ефективність навчання. Серед цих проблем можна виокремити такі:

- наявні лабораторні стенди та майстерні недостатньо оснащені сучасними приладами, пристроями й апаратами;

- більшість лабораторних стендів і навчальних майстерень уведені в дію після списання з виробництва, не відповідають сучасним вимогам, морально та фізично застаріли;

- лабораторні роботи та стенди вимагають щорічного удосконалення, яке призводить до додаткових фінансових витрат;

- через інерційність роботи або процесів на деяких лабораторних установках за відведений для них час важко проводити повторний аналіз або перевірку;

- набуття студентами достатніх навичок і досвіду роботи в певній галузі вимагає необхідності повторення занять, що не завжди виконується задля уникнення частих поломок установок і додаткових витрат на витратні матеріали.

Упровадження в навчальний процес віртуальних динамічних моделей, які можуть входити до складу віртуальних тренажерів, дає змогу усунути означені вище проблеми, а також дозволяють розв'язувати такі задачі: 
- ініціювати досить великий інтерес у студентів разом з доступністю для них;

- привернути увагу студентів, ураховуючи їх психологічні особливості;

- представити фізичні процеси в динамічному режимі;

- сприяти підвищенню ефективності проведення навчальних занять засвоєнню навчальних матеріалів, а також ефективності навчання загалом;

- забезпечити можливість самоконтролю знань з боку студентів.

Задля використання ВДМ у навчальному процесі мио розробили комплект дидактичних проектів лекцій для вивчення модулю «Силова передача та робоче обладнання тракторів і автомобілів» навчальної дисципліни «Трактори та автомобілі».

Нашою методикою передбачається використання віртуальних динамічних моделей у якості засобів візуалізації навчального матеріалу. Досліджувані нами ВДМ представляють як відео- або анімаційні ролики і потребують від викладача лише базових навичок роботи із персональним комп'ютером, без певних спеціальних знань у галузі інтелектуальних технологій, розширюючи таким чином коло потенційних користувачів.

Для прикладу розглянемо комплект ВДМ, що використовувався під час вивчення теми «Трансмісії. Муфти зчеплення» названого вище модуля. До нього увійшли такі: «Трансмісія автомобіля Шевроле Нива», «Принцип дії гідростатичної трансмісії», «Принцип роботи Суперваріатора», «Будова та принцип дії фрикційної однодискової муфти зчеплення», «Гідромуфта».

Усі названі моделі розміщені в мережі Internet у безкоштовному доступі. Вони не розроблені нами, проте певним чином редаговані і вдосконалені для зручності використання в навчальному процесі. Серед маніпуляцій, які були проведені нами 3 ВДМ, можна виокремити:

- озвучування динамічних анімацій;

- переозвучування моделі з перекладом із російської мови на українську;

- монтування відео з видаленням несуттєвих фрагментів;

- сповільнення деяких фрагментів відеозапису для зручності коментування під час демонстрації.

Варто відзначити, що під час експерименту нами використовувались ВДМ, що містять коментар у вигляді аудіодоріжки на відео, а також такі, для яких передбачено коментування викладачем у процесі демонстрації. Попередній аудіозапис коментарів до моделі є значно зручнішим для викладача і забезпечує вищий рівень синхронності відео та коментарів, але, за нашими спостереженнями, має суттєвий недолік зниження рівня уваги студентів за умови тривалого сприйняття такого матеріалу. Коментування моделі викладачем у ході демонстрації усуває цей недолік, але є дещо незручним і часто порушує синхронність коментарів і відео. Задля забезпечення оптимального сприйняття студентами навчального матеріалу ми рекомендуємо комбінувати обидва типи моделей. У випадку демонстрації довготривалих моделей із записаними коментарями варто періодично призупиняти показ і додавати власні коментарі чи зауваження задля концентрації уваги студентів.

Експериментальна перевірка ефективності застосування ВДМ у процесі фахової підготовки інженерів-педагогів проводилась серед студентів факультету технологічної i професійної освіти Глухівського національного педагогічного університету імені Олександра Довженка.

Експеримент проводився в два етапи. На констатувальному етапі педагогічного експерименту було визначено контрольні та експериментальні групи, які суттєво не різняться між собою за рівнем успішності. 
У ході формувального етапу експерименту студенти експериментального масиву вивчали спеціальні технічні дисципліни за розробленою нами методикою із використанням віртуальних динамічних моделей. Натомість студенти контрольного масиву продовжували навчання за традиційною технологією. Наприкінці цього етапу проведено вимірювання рівня сформованих знань за допомогою письмового опитування і проаналізовано стан фахової підготовки майбутніх інженерів-педагогів. У процесі складання завдань для опитування ми не використовували запитання, пов'язані з будовою вузлів і механізмів, які за своєю суттю відповідають лише репродуктивному рівню знань. Основу опитувальників складали запитання, пов'язані з принципом дії механізмів.

Дані вимірювання піддали математичній обробці. Результати показали, що середній бал у контрольній групі становить 3,42 (приріст 0,04 ), а в експериментальній групі - 3,95 (приріст 0,48). Повторне порівняння за t-критерієм Стьюдента показало, що $\mathrm{t}_{\mathrm{Eмп}}=2,9>\mathrm{t}_{\mathrm{Kp}}=2,01$ (при $\mathrm{p} \leq 0,05$ ). Отже, порівнювані вибірки суттєво різняться між собою.

Окрім того, за результатами бесід із студентами експериментальної групи можна стверджувати, що використання ВДМ під час читання лекцій із дисципліни «Трактори і автомобілі» полегшує сприймання матеріалу та підвищує рівень цікавості у слухачів лекції.

Отже, спираючись на отримані результати, можна вважати розроблену нами методику ефективною, а отже і використання віртуальних динамічних моделей, як засобу навчання $є$ доцільним і результативним.

\section{Література}

1. Жалдак М. І. Проблеми інформатизації навчального процесу в середніх i вищих навчальних закладах [Текст] / М. І. Жалдак// Комп'ютер в школі та сім'ї. № 3. - 2013. - С. 8-15. 2. Левіна І. А. Метод моделювання як засіб формування пізнавальної самостійності [Текст] / I. А. Левіна // Вісник Одеського інституту внутрішніх справ. - 1998. - №1. - С. 122-128. 3. Образцов И. В. Виртуальные тренажеры в практике технического образования [Электронный ресурс] / И. В. Образцов, В.В.Белов // Всероссийский конкурс научно-исследовательских работ студентов и аспирантов «Инновационные технологии в образовательном процессе»: сб. науч. работ. Ч. 2. - Белгород, 2011. - Режим доступа: http://cdokp.tstu.tver.ru/site.services/download.aspx?act $=1 \&$ did=89791\&dbid=marcmain. Заголовок с экрана. 4. Пинькас В. Г. Имитационное моделирование в учебном процессе медицинского вуза [Текст]/ В. Г. Пинькас // Медико-биологические проблемы промышленного региона: Сб. науч. статей ученых Луганского государственного мед. ун-та. - Вып. 1 / под ред. В. Г. Ковешникова. - Луганск : Виталина, 1997. - С. 48-50. 4. Теплицький I. О. Елементи комп'ютерного моделювання [Текст] : [навчальний посібник] / I. О. Теплицький. - Кривий Ріг : КДПУ, 2010. - 264 с. 